\title{
Irish Water Spaniel
}

National Cancer Institute

\section{Source}

National Cancer Institute. Irish Water Spaniel. NCI Thesaurus. Code C53889.

The Irish Water Spaniel is the largest of the spaniels with a solid brown (leaning to purple), crisp-textured, and curly coat. The long ears are covered with curls. The outer coat is lined with a dense undercoat, which helps insulate the dog in even the coldest water. Webbed feet assist in swimming. Height: 20-23 inches (51-58 cm.) Weight: 45-65 pounds (20-30 kg.) 